\title{
Ultralight Oxygen in Corundum-Bearing Rocks of North Karelia, Russia, as a Result of Isotope Separation by Thermal Diffusion (Soret Effect) in Endogenous Fluid Flow
}

\author{
E. Yu. Akimova, K. I. Lokhov \\ Saint-Petersburg State University, Saint-Petersburg, Russia \\ Email: 79052513147@yandex.ru,k.lokhov@spbu.ru
}

Received 11 November 2015; accepted 10 December 2015; published 17 December 2015

\begin{abstract}
Helium and argon isotopes in fluid inclusions in minerals of corundum bearing rocks with anomalous light oxygen of the Khitoostrov (North Karelia, Russia) were studied. It was found that atmospheric noble gas component is missing. Therefore, all previously proposed models of participation in the fluid surface ice meltwater are not valid. Proposed and justified endogenous mechanism of isotope fractionation of oxygen and other chemical elements by the mechanism of thermal diffusion. Geologically justified existence of the cascading effect for a number of the separation thermodiffusion cells, which lead to significant isotope effects. Cascading is realized due to the "fluid pump", in which role are acting amphibolized gabbro in the contact with corundum metasomatites. It is assumed that the mechanism is not specific for the case corundum metasomatic rocks, which are a special case of manifestation of such a scenario in processes involving endogenous fluid flows.
\end{abstract}

\section{Keywords}

Corundum-Bearing Rocks, Noble Gas Isotopes, Anomaliously Light Oxygen, Thermodiffusion, Natural Fluid Pump

\section{Introduction}

Corundum-bearing metasomatic rocks of North Karelia occur in some localities within the Belomorian mobile belt (BMB). These rocks are connected with the aluminous gneisses of the Chupa complex and the shear zones, which in all cases are close to gabbro intrusions, partially amphibolized at the contact with metasomatites. These metasomatic rocks are characterized by unique oxygen isotope composition: $\delta^{18} \mathrm{O}$ down to -27\%o (Vienna standard mean ocean water, or VSMOW) [1]-[3], and are anomalous in comparison with all known silicate Earth’s rocks which have positive $\delta^{18} \mathrm{O}$ values [4]. 


\section{Existing Models for Ultralight Oxygen}

A lot of models, which have been proposed for the genesis of these rocks, are based on the idea that glacial meltwaters contributed into the fluid that was responsible for the formation of these rocks, because only the subpolar glaciers are characterized by extremely light oxygen ( $-30 \%$ - $-40 \%$ ). These models may be divided into three groups:

- Infiltration of glacial meltwaters from the surface to the depth about $20 \mathrm{~km}$ towards the endogenous zone of mineral formation [2] [5] [6].

- Volcanism beneath the glacier, prior to the formation of metasomatic rocks [3] [7] [8].

- Formation of ultralight protolith due to the interaction between glacial meltwaters and mafic intrusions before the metamorphism [1] [9].

The foregoing models have a lot of contradictions with the existing geologic, petrologic and geochronologic data.

Particularly evident is the assumption of glacial meltwaters infiltration to the depth about $20 \mathrm{~km}$ without interaction with the host rocks. Also the participation of glacial melt waters in the formation of metasomatic fluid assumes that the area of BMB in the Paleoproterozoic was in the high-latitude zone which contradicts the paleomagnetic data [10]. Furthermore, Paleoproterozoic volcanic rocks are not known within the Belomorian mobile belt [11].

The role of endogenous and surface waters connected with an atmospheric reservoir can be estimated by investigation of noble gas isotopic geochemistry, in particular, argon and helium isotopic geochemistry. Difference in isotopic ratios of these elements in surface waters and deep-seated fluids is at least one order of magnitude [12] [13].

Samples of Khitoostrov corundum-bearing rocks with anomalous oxygen isotopic composition and samples of host rock with anomalous and normal $\delta^{18} \mathrm{O}$ values were investigated to identify the presence of surface component in the fluid.

\section{Helium and Argon Isotopic Geochemistry}

Analysis of argon and helium isotope composition in gas-liquid inclusions contained in minerals were carried out at the Centre of Isotopic Research of the A. P. Karpinsky Russian Geological Research Institute by the method [14] of vacuum crushing to extract trapped gas from fluid inclusions and isotopic measurements on the isotopic static gas mass-spectrometer Micromass NG-5400. The results are presented in Table 1. Oxygen isotopic composition of the samples were obtained previously and described in [1].

Probable contribution of cosmogenic component was evaluated because some samples were collected from the surface, except metasomatic rocks. In situ production of nucleogenic helium was possible by reaction ${ }^{6} \mathrm{Li}(\mathrm{n}, \alpha)^{3} \mathrm{H}$ $\rightarrow{ }^{3} \mathrm{He}$. Estimated input of cosmogenic and nucleogenic helium could affect the ${ }^{3} \mathrm{He} /{ }^{4} \mathrm{He}$ ratio less than to $10 \%$.

Solubility data for noble gas in water [12] is used to estimate the noble gas concentration in the surface water produced by melting of high latitude glaciers. Estimations for argon and helium in the endogenous fluid were evaluated by the data for the noble gas isotopic and elemental ratios in endogenous continental rocks: ${ }^{3} \mathrm{He} /{ }^{36} \mathrm{Ar}=$ $0.001-0.1 ; \mathrm{CO}_{2} /{ }^{36} \mathrm{Ar}=10^{9}-10^{10} ; \mathrm{CO}_{2} / \mathrm{H}_{2} \mathrm{O}=0.05-0.15$ [15], so the calculated ${ }^{36} \mathrm{Ar}$ concentration in the fluid

Table 1. Helium and argon isotope composition in the rocks of Khitoostrov locality.

\begin{tabular}{|c|c|c|c|c|c|c|c|}
\hline \multirow{2}{*}{ Sample } & \multicolumn{7}{|c|}{ Isotopic research results } \\
\hline & $\delta^{18} \mathrm{O}, \%$ & ${ }^{4} \mathrm{He}, 10^{-6} \mathrm{~cm}^{3} / \mathrm{g}$ & ${ }^{3} \mathrm{He} /{ }^{4} \mathrm{He}, 10^{-6}$ & ${ }^{4} \mathrm{He} /{ }^{20} \mathrm{Ne}$ & ${ }^{4} \mathrm{He} /{ }^{40} \mathrm{Ar}$ & ${ }^{40} \mathrm{Ar}, 10^{-6} \mathrm{~cm}^{3} / \mathrm{g}$ & ${ }^{40} \mathrm{Ar} /{ }^{36} \mathrm{Ar}$ \\
\hline Gabbro & +5.7 & 1.54 & 0.09 & 440 & 0.41 & 3.90 & 8186 \\
\hline Amphibolizated gabbro & -5.5 & 7.06 & 0.07 & 805 & 1.05 & 7.00 & 7718 \\
\hline Metasomatic rock & -7.3 & 0.72 & 0.26 & 131 & 0.12 & 6.20 & 4532 \\
\hline Metasomatic rock & -9.0 & 1.62 & 0.25 & 328 & 0.12 & 13.90 & 4895 \\
\hline Gneiss & +8.8 & 1.54 & 0.19 & 478 & 0.21 & 7.90 & 5832 \\
\hline Gneiss & +8.1 & 48.10 & 0.10 & 353 & 6.20 & 8.20 & 5247 \\
\hline
\end{tabular}


is from $2.5 * 10^{-7}$ to $2.5 * 10^{-6} \mathrm{~cm}^{3} / \mathrm{mol} \mathrm{H}_{2} \mathrm{O}$, and ${ }^{3} \mathrm{He}$-from $2.5 * 10^{-9}$ to $2.5 * 10^{-7} \mathrm{~cm}^{3} / \mathrm{mol} \mathrm{H}_{2} \mathrm{O}$. The mixing lines were calculated to specify a possible model of the surface melted water and the endogenous fluid mixing (Figure 1).

Calculated mixing lines for the metamorphic fluid and surface water do not fit the experimental points. This means, that participation of any surface water, including glacial meltwater, in formation of fluid with the anomalously light oxygen is impossible. That also relates to hypothetic pre-metamorphic alteration zones in mafic intrusions. Isotopic data point to the participation of endogenous fluid in corundum-bearing rock formation, so rock forming fluid in the shear zone was depleted in heavy oxygen isotopes for some reason.

Isotopic data for helium combined with elemental ${ }^{4} \mathrm{He} /{ }^{40} \mathrm{Ar}$ ratio (Figure 2) demonstrate: 1) preferential loss of helium took place in the shear zone, which confirms the existence of thermal gradient between the central hotter

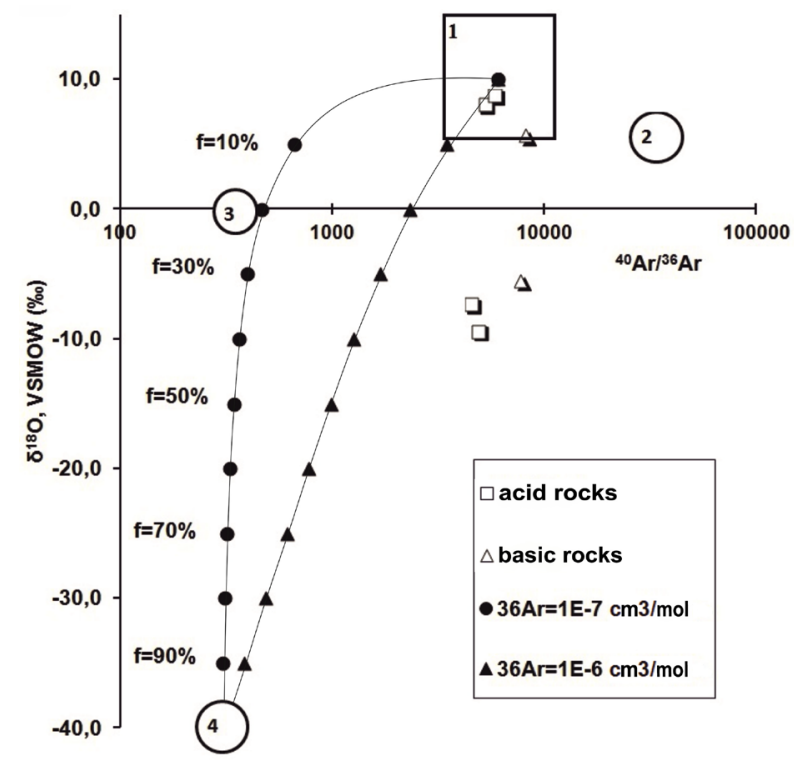

Figure 1. Experimental data for argon and calculated mixing lines for surface and endogenous fluid. $\mathrm{f}-$ mixing factor (proportion of surface water). Composition fields: 1 -continental metamorphic rocks, 2 - upper mantle, 3-ocean water, 4-high latitude glaciers.

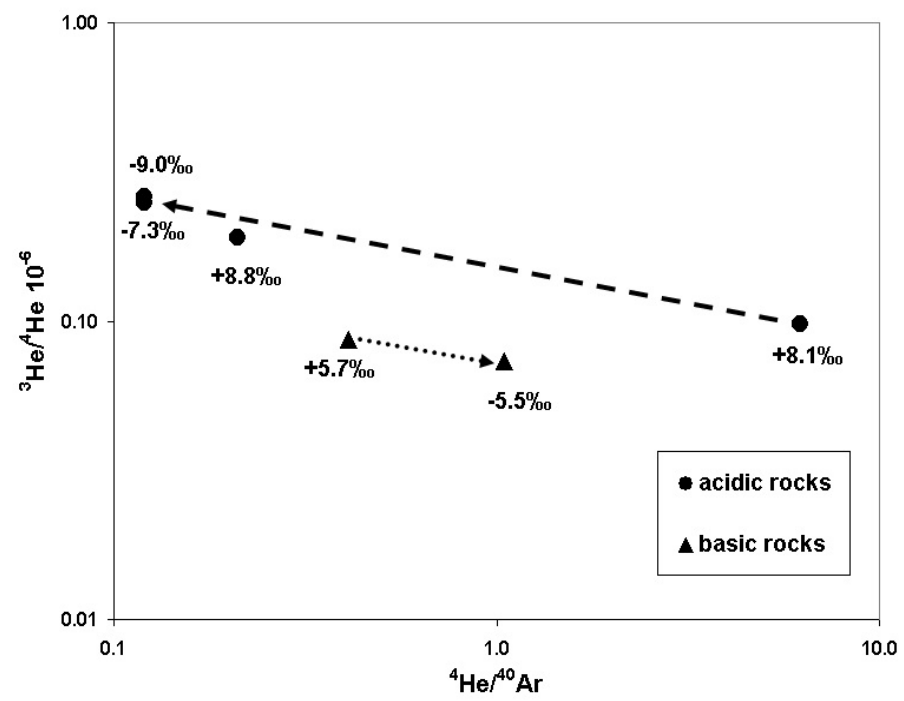

Figure 2. Dependence of the isotopic ratio ${ }^{3} \mathrm{He} /{ }^{4} \mathrm{He}$ on the ratio ${ }^{4} \mathrm{He} /{ }^{40} \mathrm{Ar}$. Dotted arrows show the change of the fluid parameters from the host rocks to the centre of the shear zone with corundum rocks. 
part of the shear zone and the colder outer host rocks for the gneisses, and just opposite scenario was for the amphibolized gabbro as compared to unalterated gabbro; 2) essential increase of ${ }^{3} \mathrm{He} /{ }^{4} \mathrm{He}$ isotopic ratio (up to $1000 \%$ o) in the metasomatic rocks in the central part of the shear zone in comparison with the host gneisses and the opposite effect is observed in the altered and primary gabbros; 3) correlation between the first two effects.

Helium and oxygen isotopic compositions correlate in the system. Light isotopes $\left({ }^{3} \mathrm{He}\right.$ and $\left.{ }^{16} \mathrm{O}\right)$ are concentrating in the central hot part and the heavy isotopes $\left({ }^{4} \mathrm{He}\right.$ and $\left.{ }^{18} \mathrm{O}\right)$ are concentrating in the outer cold part, especially in amphibolized gabbro. Isotopic effect for helium is much stronger, than for oxygen, so isotopic fractionation of oxygen is mass depended and has no connection with isotopic exchange effects between the fluid and the rock.

\section{Thermodiffusion Model for a Fluid-Permeable Zone}

The results may suggest that isotope and element fractionation in the fluid system was realized by thermodiffusion mechanism (Soret effect). It leads to separation according the molecular or isotopic mass due to the temperature gradient in the system. Such conditions can be realized in the fluid permeable shear zones. The effect of isotope separation, or molecular combinations with various mass, by thermodiffusion is described in terms of the non-equilibrium thermodynamics [16] [17] and leads to concentration of the light species (and light isotopes) in the central hotter part of the system.

During metasomatism the fluid migrates from the hot center part of the permeable zone into the colder host rock by means of the external convection and according the foregoing mechanism the host rocks are enriching in heavier oxygen and helium isotopes. Gabbro amphibolization takes place under the influence of the fluid and the growing amphibole traps into its crystal cell a portion of the fluid as the $(\mathrm{OH})^{-}$groups, which are enriched in the heavy isotopes, i.e. amphibole is a pump analogue. The factor of isotopes separation in the individual thermodiffusion cell is very small and close to unity, however the effect can be greatly increased by cascading of cells [18]. During this process each part of shear zone with better permeability is an individual vertical cell, where isotopes are undergoing separation. Therefore the foregoing mechanism is multiplied in the rocks and the cascading mechanism can be realized (Figure 3).

In nature, thermal diffusional mechanism of isotope separation with cascading of elementary separating cells requires the removal of fluid from the cold outer part of the shear zone, i.e. it demands a special "fluid pump". Intrusive gabbroids amphibolized at the contacts with corundum-bearing plagioclasites in the fluid permeable shear zones (Figure 3) can play the role of such pumps. It is the difference between the studied corundumbearing rocks and analogous metasomatic rocks in the other complexes where no anomalous isotopic composition of oxygen was found.

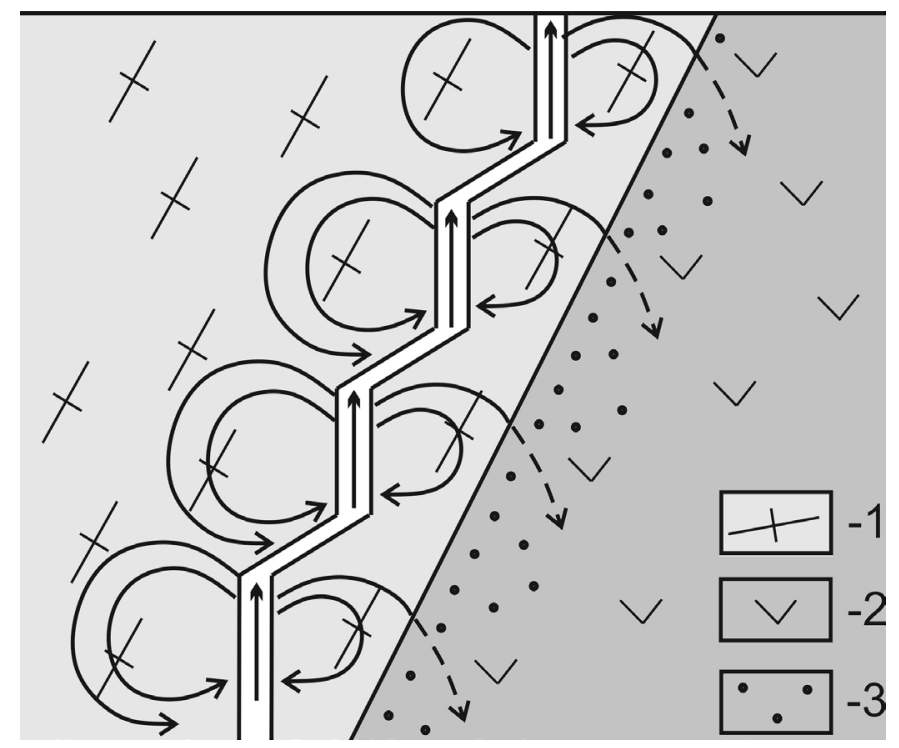

Figure 3. The structure of the shear zone with a cascade of thermodiffuzion cells. Arrows indicate fluid circulation by external convection. Legend: 1-gneisses, 2gabbros, 3-amphibolization zone in gabbros (the "fluid pump"). 
Initial water-rock ratio (W/R) is from 0.01 to 0.06 at the entrance of the separation column, i.e. from 1 to 6 weight percents of $\mathrm{H}_{2} \mathrm{O}$, as follows from estimations of ${ }^{40} \mathrm{Ar}$ concentration and ${ }^{40} \mathrm{Ar} /{ }^{36} \mathrm{Ar}$ ratio in metasomatic rocks (Table 1) and from estimation of $\mathrm{CO}_{2}{ }^{36} \mathrm{Ar}=10^{9}-10^{10}, \mathrm{CO}_{2} / \mathrm{H}_{2} \mathrm{O}=0.05-0.15$ in the endogenous fluid and from estimation of the Rayleigh exhaustion factor $\boldsymbol{f}=0.0007$. From 0.5 to 2.5 volume fraction of the amphibolites developed over gabbro should account for a single elementary volume of the metasomatic rock, as follows from the estimation of volume fraction of water in amphibolites developed over gabbros, average 2.5 2.7 weight $\% \mathrm{H}_{2} \mathrm{O}$. This is consistent with the geological settings of locations according to the geological schemes and cross-sections [1] [2] [7].

The absence of isotopic equilibrium in coexisting minerals of corundum metasomatites [19] and marked out in [3] also indicates the thermal diffusion mechanism, under the influence of which the thermodynamic equilibrium is impossible. This can be applied to the local equilibrium as well.

The foregoing model is suitable for describing all localities of corundum-bearing rocks within the Belomorian mobile belt in a single process [20]. Localities with the weak effect of oxygen isotope separation are on the bottom of the separation column cascade and localities with the strong effect are on the top of the separation column.

Further isotopic research of these objects is necessary to clarify the present model. It is expected that classic metasomatic zoning in similar objects can be disturbed by thermodiffusion mechanism.

\section{Acknowledgements}

We thank Dr. P. Ya. Azimov (IPGG RAS, St. Petersburg) for the samples for this study and Prof. E. M. Pasolov (VSEGEI, St. Petersburg) for the help with analytical work.

This work was partly supported by Saint-Petersburg State University grant 3.37.86.2011.

\section{References}

[1] Bindeman, I.N. and Serebryakov, N.S. (2011) Geology, Petrology and O and H Isotope Geochemistry of Remarkably 180 Depleted Paleoproterozoic Rocks of the Belomorian Belt, Karelia, Russia, Attributed to Global Glaciation 2.4 Ga. Earth and Planetary Science Letters, 306, 163-174. http://dx.doi.org/10.1016/j.epsl.2011.03.031

[2] Krylov, D.P. (2008) Anomalous Ratios of 18O/16O in Corundum-Bearing Rocks from Northern Karelia. Dokl. Earth Sci., 419, 533-536.

[3] Vysotskiy, S.V., Ignatiev, A.V., Levitskiy, V.I., Budnitskiy, S.Yu. and Velivetskaya, T.A. (2011) New Data on Stable Isotopes in Minerals of Corundum-Bearing Rocks, North Karelia (Russia). Dokl. Earth Sci, 439, 95-98.

[4] Hoefs, J. (2004) Stable Isotope Geochemistry. 5th Edition, Springer, Berlin, 244 p.

[5] Krylov, D.P., et al. (2011) Age and Origin of the Corundum-Bearing Rocks of Khitostrov Island, Northern Karelia. Petrology, 19, 79. http://dx.doi.org/10.1134/S086959111101005X

[6] Krylov, D.P., Glebovitsky, V.A., Skublov, S.G. and Tolmacheva, E.V. (2012) Rare-Earth Elements in Zircons of Diverse Age from Corundum-Bearing Rocks of Khitostrov (Northern Karelia). Doklady Akademii Nauk, 443, 352-357.

[7] Vysotskiy, S.V., Ignatiev, A.V., Yakovenko, V.V. and Karabtsov, A.A. (2008) Anomalous Light Oxygen Isotope Composition in Minerals of Corundum-Bearing Rocks in Northern Karelia. Dokl. Earth Sci., 423, 1216-1219.

[8] Vysotskiy, S.V., Nechaev, V.P., Kissin, A.Yu., Yakovenko, V.V., Ignat'ev, A.V., Velivetskaya, T.A., Sutherland, F.L. and Agoshkov, A.I. (2015) Oxygen Isotopic Composition as an Indicator of Ruby and Sapphire Origin: A Review of Russian Occurrences. Ore Geology Reviews, 68, 164-170. http://dx.doi.org/10.1016/j.oregeorev.2015.01.018

[9] Bindeman, I.N., Serebryakov, N.S., Schmitt, A.K., Vazquez, J.A., Guan, Y., Azimov, P.Ya., Astafiev, B.Yu., Palandri, J. and Dobrzhinetskaya, L. (2014) Field and Microanalytical Isotopic Investigation of Ultradepleted in ${ }^{18}$ O Paleoproterozoic “Slushball Earth” Rocks from Karelia, Russia. Geosphere, 10, 308-339. http://dx.doi.org/10.1130/GES00952.1

[10] Lubnina, N.V. (2009) Magnetic Reversal of East-European Craton Rocks. Vestnik Kraesc. Earth Sciences, 2, 19-28. (In Russian)

[11] Miller, Yu.V. and Milkevich, R.I. (1995) Tectonic Cover-Folded Structure of the Belomorian Belt and Its Relations with the Karelian Granite-Greenschist Region. Geotectonics, 6, 80-92.

[12] Ozima, M. and Podosek, F. (2004) Noble Gas Geochemistry. Cambridge University Press, Cambridge, 286 p.

[13] Verkhovskiy, A.B. and Shukolyukov, Yu.A. (1991) Elemental and Isotopic Fractionation of Noble Gas in Nature. M.: Science, 294 p. (In Russian)

[14] Prasolov, E.M., Lokhov, K.I. and Krupenik, V.A. (2011) Helium and Argon Isotopic Composition in Halite. In Book 
Paleoproterozoic Onega Structure (Geology, Tectonics, Deep Structure and Mineralogy) red. L.V. Glushanin, N.V. Sharov, V.V. Shiptsov. Petrozavodsk, publ. Scientific Centre of Karelia DAN, 432 p. (In Russian)

[15] Lokhov, K.I. and Levsky, L.K. (1996) Carbon and Heavy Noble Gas Isotopes in Methamorphic Fluids. Geochemistry International, 33, 23-31.

[16] Eslamian, M. (2011) Advances in Thermodiffusion and Thermophoresis (Soret Effect) in Liquid Mixtures. Frontiers in Heat and Mass Transfer (FHMT), 2, 043001.

[17] Jones, R.C. and Ferry, W.H. (1946) The Separation of Isotopes by Thermal Diffusion. Rev. Mod. Phys., 18, 151-224.

[18] Rozen, A.M. (1960) The Theory of the Separation of Isotopes in the Columns. M.: Atomizdat, 437 p. (In Russian)

[19] Sedova, I.S., Baikova, V.S., Lokhov, K.I. and Klepinin, S.L. (1999) Features of Fluid Components Distribution in Some Intrusive Rocks of Baltic Shield (Pon'gom-Navolok Island). Zap. RMS, CXXVIII, 34-47. (In Russian)

[20] Lokhov, K.I., Prasolov, E.M., Akimova, E.Yu., Lokhov, D.K. and Bushmin, S.A. (2016) Ultralight Oxygen in Corundum-Bearing Rocks of Northern Karelia, Russia, as a Result of Isotope Separation by Thermodiffuzion (Soret Effect) in Endogenous Fluid Flow. Vestnik SPbSU, 7. (Accepted Paper in Russian) 